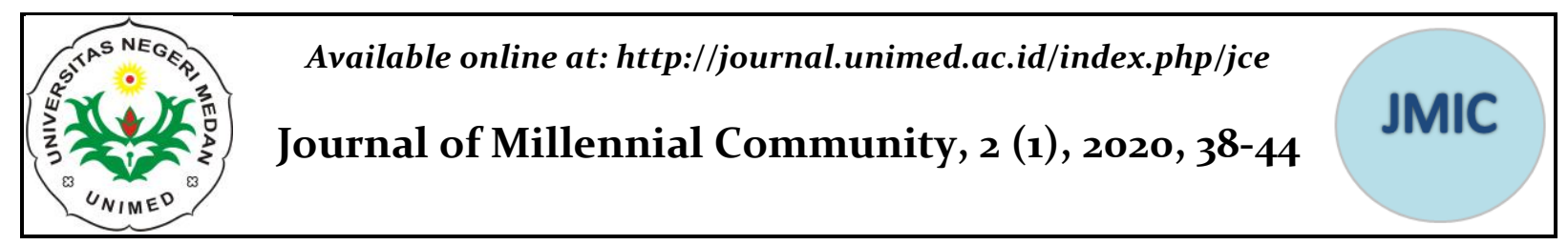

\title{
Pengembangan Kompetensi Guru dalam Membuat Pola Digital dengan Menggunakan CAD System
}

\author{
Nurhijrah $^{1 *}$, Nasrah Natsir ${ }^{2}$ \\ ${ }^{1}$ Pendidikan Kesejahteraan Keluarga, Universitas Negeri Makassar. Jalan Daeng Tata Raya \\ Parang Tambung, Makassar, Indonesia \\ ${ }^{2}$ Pendidikan Luar Sekolah, Universitas Negeri Makassar. Jalan AP.Pettarani \\ Makassar, Indonesia \\ *Email:nurhijrah@unm.ac.id, nasrahnatsir@gmail.com
}

\begin{abstract}
Abstrak
Pengembangan kompetensi guru dalam membuat pola digital dengan menggunakan $C A D$ System bertujuan untuk mengembangkan kompetensi guru SMK Tata Busana dalam membuat pola digital dengan menggunakan CAD System, metode yang digunakan dalam penelitian ini penelitian pengembangan (R\&D) dan mengacu pada model pengembangan ADDIE yaitu: analysis, Design, Development, Implementation, Evaluation dengan subjek uji coba adalah guru SMK Tata Busana Se-Kota Makassar. Hasil penelitian menunjukkan adanya peningkatan kompetensi guru SMK Tata Busana dalam membuat pola dengan melihat peningkatan dalam setiap indikator penilaian yang rata-rata berada pada kriteria sangat kompeten setelah melakukan pretest dan postest.
\end{abstract}

Kata Kunci: kompetensi guru, CAD system, pola

\section{Teacher Competency Development in Making Digital Patterns Using The CAD System}

\begin{abstract}
The development of teacher competency in making digital patterns by using the CAD System aims to develop the competency of teachers in Clothing Design Vocational School in making digital patterns by using the CAD System, the method used in this research is research and development (RED) and refers to the ADDIE development model namely: analysis, Design, Development, Implementation, Evaluation with the test subject is the Makassar Vocational School Clothing teacher. The results showed an increase in the competence of the Vocational School dressmaking teachers in making patterns by seeing an increase in each assessment indicator that on average were in the very competent criteria after doing the pretest and posttest.
\end{abstract}

Keywords: Teacher competency, CAD System, Pattern

\section{PENDAHULUAN}

Dalam memajukan dunia pendidikan peran guru sangatlah penting dalam mengajar dan mendidik siswa. Oleh karena itu seorang guru harus memiliki kompetensi yang sesuai dengan standar nasional pendidikan, hal ini bertujuan agar seorang guru dapat menjalankan tugas dan tanggung jawabnya dengan baik. Sejalan dengan kebijakan pemerintah, dalam UU No.14
Tahun 2005 tentang Guru dan Dosen Pasal 20, dalam menjalankan tugas keprofesionalan, guru berkewajiban meningkatkan dan mengembangkan kualifikasi akademik dan kompetensi secara berkelanjutan sejalan dengan perkembangan ilmu pengetahuan, teknologi, dan seni (Undang-undang Guru dan Dosen, 2014)

Guru membutuhkan pelatihan yang mampu menambah wawasan dan 
meningkatkan keterampilan mereka. Suatu pelatihan akan bermanfaat jika guru memiliki semangat belajar yang tinggi tanpa memandang dari segi umur. Semangat belajar ini harus melekat dalam diri seorang guru sehingga mereka kaya akan akan ilmu dan terampil. Dalam mengembangkan kompetensinya guru dapat belajar melalui program pelatihan dari sekolah maupun luar sekolah dan dari sarana dan prasarana sekolah, sehingga guru diharapkan mampu bersikap professional dalam proses pendidikan dan pengajaran (Musfah, 2011: 11). Tugas seorang guru adalah bagaimana mampu menciptakan proses belajar mengajar yang memberikan harapan, bukan yang menakutkan. Dalam proses mengajar dan mendidik setiap guru perlu memiliki kesabaran dan kasih saying terhadap para siswanya, hingga mereka betul-betul menjadi pribadi yang dewasa. Menurut Suparman (2012: 65) Kompetensi adalah hasil kombinasi antara pengetahuan, keterampilan dan perilaku yang digunakan untuk meningkatkan kinerja, atau keadaan atau kualitas yang memadai atau sangat berkualitas, mempunyai kemampuan untuk menampilkan peran tertentu. Kompetensi guru adalah kemampuan yang harus dimiliki oleh seorang guru dalam merencanakan dan melaksanakan proses belajar mengajar (Kartowagiran, 2011).

Perkembangan teknologi semakin hari semakin berkembang dengan pesat. Tidak dapat dipungkiri bahwa sekarang ini segala aktifitas tidak lepas dengan perkembangan teknologi begitupun pada bidang pendidikan. Pada era 4.0 sebagian besar bentuk pembelajaran telah memanfaatkan teknologi informasi, internet dll. Kebutuhan akan peningkatan penguasaan ilmu dan teknologi pada masa sekarang semakin dirasakan, perkembangan dunia industri juga menuntut untuk terus belajar mengenai penerapan teknologi sebagai sarana peningkatan produktivitas. Salah satu yang banyak digunakan oleh dunia industry masa kini adalah mesin potong kain dengan menggunakan komputer. Pembuatan pola digital nantinya akan digunakan dalam pemotongan kain dengan mesin potong komputer. Oleh karena itu, penguasaan pembuatan pola digital dengan menggunakan CAD System ini menjadi suatu keharusan. CAD (Computer Aided Design) adalah suatu program komputer baik software maupun hardware untuk membuat suatu desain beserta dokumentasi (Laidiah dkk, 2017: 1).

Permasalahan pokok yang terjadi pada bidang pendidikan saat ini adalah minimnya kompetensi guru dalam memanfaatkan teknologi dalam menunjang proses belajar mengajar. Sedangkan seorang guru dituntut untuk terus meningkatkan kompetensi yang dimiliki. Pengembangan kompetensi guru memiliki hubungan dengan peningkatan sumber daya manusia sedangkan pendidikan selalu sejalan dengan perkembangan teknologi dan manusia.

Berdasarkan hasil observasi, guru SMK Tata Busana di Kota Makassar belum memiliki keterampilan dalam membuat pola secara digital. Proses membuat pola masih menggunakan teknik manual yang membutuhkan banyak waktu untuk menyelesaikannya, sedangkan pada kurikulum 2013 menyebutkan adanya kebutuhan pola digital sesuai dengan perkembangan kebutuhan pada dunia industri masa kini.

Guru SMK Tata Busana memerlukan kompetensi dalam membuat pola digital dengan menggunakan $C A D$ system dengan harapan agar guru SMK Tata Busana memiliki kemampuan dan ketertarikan untuk belajar membuat pola digital dengan menggunakan $C A D$ system dan menularkannya pada siswa SMK khususnya siswa SMK jurusan Tata Busana.

Tujuan dari penelitian ini adalah untuk mengembangkan kompetensi guru dalam membuat pola digital dengan menggunakan CAD System. Manfaat penelitian adalah dapat menambah ilmu pengetahuan dibidang pendidikan khususnya dalam peningkatan keterampilan membuat pola digital, sebagai bahan acuan bagi setiap pengajar dalam melaksanakan proses pembelajaran.

\section{METODE}

Penelitian ini merupakan penelitian pengembangan R\&D (Research and 


\section{Journal of Millennial Community, 2 (1), March 2020 - 1}

Nurhijrah, Nasrah Natsir

Development) yang mengacu pada model pengembangan ADDIE. Penelitian ini dilaksanakan di Makassar pada Desember 2019. Subjek penelitian adalah Guru SMK Tata Busana se- Kota Makassar. Jenis data yang digunakan adalah data kuantitatif dan kualitatif. Data kuantitatif dihimpun dengan menggunakan angket penilaian, sedangkan data kualitatif akan dihimpun melalui hasil penilaian, masukan, kritik, tanggapan dan saran perbaikan yang diperoleh melalui wawancara dan hasil observasi. Instrument dalam penelitian ini berupa wawancara, observasi, dan kuesioner. Teknik analisis data adalah dengan menggunakan analisis deskriptif. Adapun tahapan penelitian antara lain:

Analysis

Pada tahap ini terdapat 2 kegiatan yaitu Tahap pertama adalah menganalisis kinerja yaitu menganalisis kinerja yang dihadapi di SMK dengan memberikan solusi. Tahap kedua adalah menganalisis kebutuhan yaitu menganalisis kebutuhan yang diperlukan untuk menentukan kompetensi yang dibutuhkan oleh peserta.

Design

Tahap design meliputi: menentukan kebutuhan pembelajar, merumuskan tujuan pembelajaran, menentukan kurikulum serta melaksanakan pelatihan.

Development

Pada tahap development adalah tahap realisasi produk yaitu tahap pembuatan skenario pembelajaran, dan modul pelatihan membuat pola dengan $C A D$ System yang merupakan media cetak. Sebelum merealisasikan pelaksanaan penelitian terlebih dahulu melakukan validasi oleh validator, setelah dinyatakan layak maka produk telah siap digunakan pada tahap implementasi.

Implementatition

Tahap implementasi adalah tahap untuk merealisasikan kegiatan pelatihan yang bertujuan untuk meningkatkan kompetnsi guru SMK Tata Busana dalam membuat pola.

Evaluation

Tahap evaluasi diambil dari hasil implementasi kegiatan berupa hasil pretest dan postest guru-guru SMK Tata Busana sebelum dan sesudah mengikuti kegiatan.

\section{HASIL DAN PEMBAHASAN (70\%)}

Ketercapaian tujuan penelitian dapat diketahuo dari pembahasan sebagai berikut: a. Analysis

Kegiatan utama pada tahap ini terdiri atas 2 tahap: tahap pertama yaitu menganalisis kinerja adalah kegiatan yang dilakukan untuk menganalisis masalah kinerja yang terjadi pada guru SMK Tata Busana se-kota Makassar dengan memberikan solusi dengan melaksanakan pelatihan untuk peningkatan komptensi guru. Tahap kedua adalah analisis kebutuhan yaitu menentukan kompetensi apa yang dibutuhkan oleh guru-guru SMK Tata Busana di Makassar. Berdasarkan hasil observasi yang dilakukan diperoleh informasi bahwa sebagian besar gurur SMK Tata Busana di Makassar belum mengetahui pembuatan pola digital menggunakan $C A D$ System.

\section{b. Design}

Tahap selanjutnya adalah tahap desain, pada tahap ini merupakan tahap persiapan rancangan model pelatihan membuat pola digital menggunakan CAD System yang mengacu pada 4 tahapan model CEM yaitu menentukan kebutuhan pembelajar: berdasarkan analisis kebutuhan peneliti menyimpulkan dengan memberikan pelatihan pembuatan pola digital dengan CAD System, merumuskan tujuan pembelajaran: berdasarkan hasil analisis tujuan pelatihan adalah untuk meningkatkan kompetensi guru dalam membuat pola digital, menentukan kurikulum: berdasarkan analisis instruksional, materi utama dalam pelatihan yaitu pengenalan program $C A D$, mengenal tool RP-DGS, pembuatan pola blus, pembuatan pola rok, serta melaksanakan pelatihan untuk peningkatan kompetensi: pelaksanaan pelatihan membuat pola digital menggunaka CAD System dilaksanakan pada bulan Desember 2019.

c. Development

Tahap pengembangan terdiri dari beberapa kegiatan:

1. Pengembangan Model Pelatihan 


\section{Journal of Millennial Community, 2 (1), March 2020 - 1 \\ Nurhijrah, Nasrah Natsir}

Kegiatan yang dilaksanakan pada tahap ini adalah realisasi rancangan produk, tahap rancangan produk ini meliputi pembuatan silabus yaitu merumuskan indikator untuk mencapai tujuan pembelajaran, menyusun skenario pembelajaran yaitu tahap-tahap pelaksanaan pembelajaran di kelas, menyusun modul pelatihan membuat pola digital menggunakan CAD System dengan materi pengenalan program $C A D$, mengenal tool RP-DGS, pembuatan pola blus, pembuatan pola rok.

2. Validasi Produk Pelatihan

Silabus dikembangkan sesuai dengan kuriku;um 2013. Dari hasil pengembangan ini diharapkan tidak menyalahi atau keluar dari materi yang digunakan. Adapun hasil validasi untuk silabus memperoleh rerata 4,53 yang berada pada kategori sangat valid. Dapat dilihat pada diagram dibawah ini:

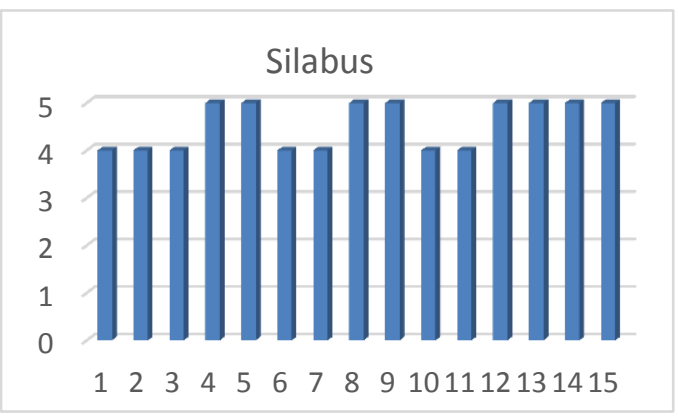

Gambar 1. Diagram batang hasil validasi silabus

Selanjutnya adalah skenario pembelajaran adalah sintaks pembelajaran dengan kegiatan dan waktu yang digunakan. Hasil validasi menunjukkan pada rerata 4,66 yang berada pada kategori sangat valid. Dapat dilihat pada diagram dibawah ini:

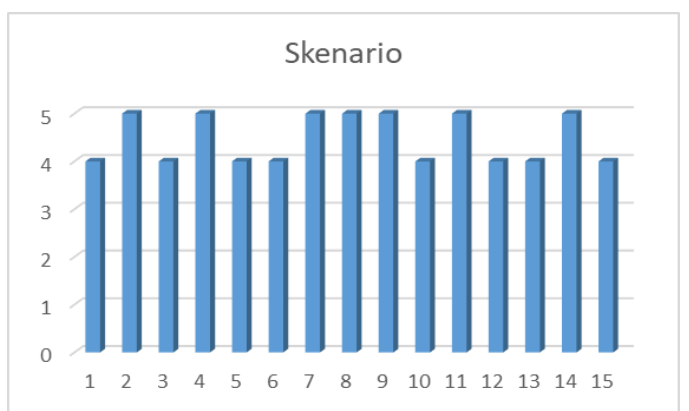

Gambar 2. Diagram batang hasil validasi skenario.

Modul pelatihan membuat pola digital dengan $C A D$ System adalah modul dengan uraian materi pengenalan program $C A D$, mengenal tool RP-DGS, pembuatan pola blus, pembuatan pola rok. Hasil validasi modul berada pada rerata 4,33 yang berada pada kategori valid. Dapat dilihat pada diagram dibawah ini:

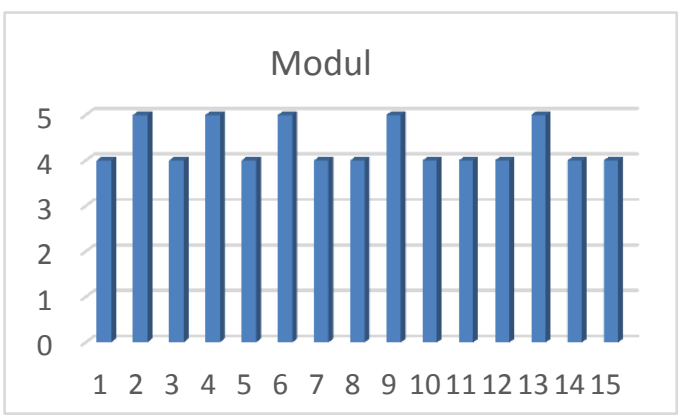

Page | 41

Gambar 3. Diagram batang hasil validasi modul

\section{d. Implementation}

Tahap implementasi adalah tahap realisasi kegitan yaitu melatih guru-guru dalam mengembangkan kompetensi dalam hal pembuatan pola. Kegiatan ini melibatkan sebanyak 15 orang guru produktif dari masing-masing SMK Jurusan Tata Busana yang ada di kota Makassar. Sebelum memberi pelatihan terlebih dahulu guruguru SMK Tata Busana diberikan pretest dengan pembuatan pola dengan menggunakan teknik manual. Setelah pelatihan guru-guru tersebut kemudian diberikan postest dengan menggunakan CAD System dalam pembuatan pola. Berikut ini adalah indikator penilaian dalam membuat pola naik secara manual maupun dengan menggunakan CAD System.

1. Ketepatan ukuran dalam membuat pola Sebelum memberikan pelatihan membuat pola digital terlebih dahulu dilakukan pretest untuk mengukur ketepatan ukuran dalam membuat pola secara manual. Hasil pretest menunjukkan rerata 1,8 yang menunjukkan bahwa kompetensi tersebut berada pada kategori kurang kompeten. Dapat dilihat pada diagram dibawah ini: 


\section{Journal of Millennial Community, 2 (1), March 2020 - 1}

Nurhijrah, Nasrah Natsir

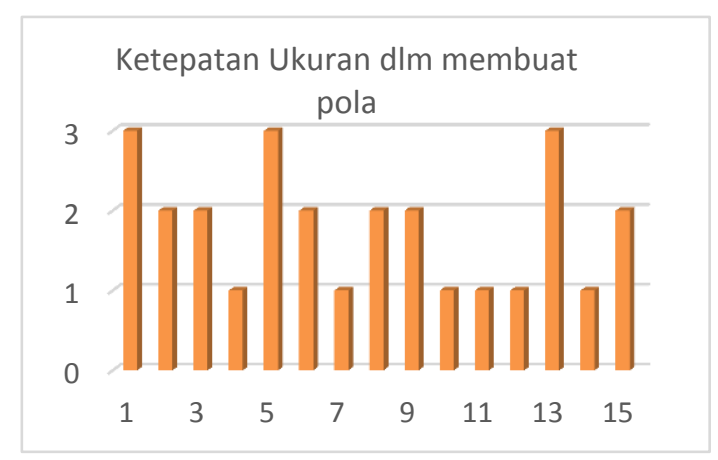

Gambar 4. Hasil pretest ketepatan ukuran dalam membuat pola

Hasil postest setelah pelaksanaan pelatihan pada indikator ketepatan ukuran dalam membuat pola memperoleh rerata 4,40 dan berada pada kategori kompeten. Dapat dilihat pada diagram dibawah ini:

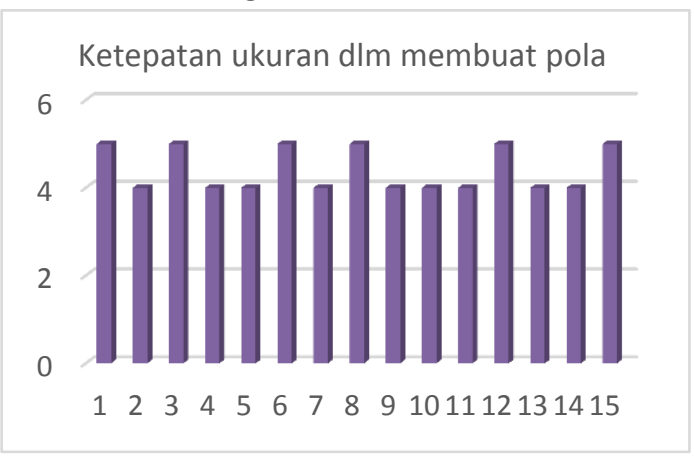

Gambar 5. Hasil postest ketepatan ukuran dalam membuat pola

2. Ketepatan dalam membuat pola rok

Indikator selanjutnya adalah ketepatan dalam membuat pola rok. Setelah melaksanakan pretest nilai rerata yang di peroleh pada indikator ketepatan dalam membuat rok adalah 2,07 yang berada pada kategori kurang kompeten. Dapat dilihat pada diagram dibawah ini:

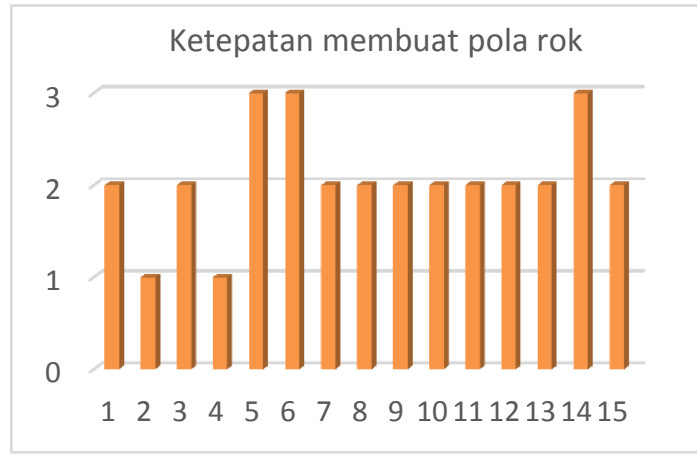

Gambar 6. Hasil pretest ketepatan membuat pola rok

Hasil postest setelah pelaksanaan pelatihan pada indikator ketepatan membuat pola rok memperoleh rerata 4,80 dan berada pada kategori sangat kompeten. Dapat dilihat pada diagram dibawah ini:

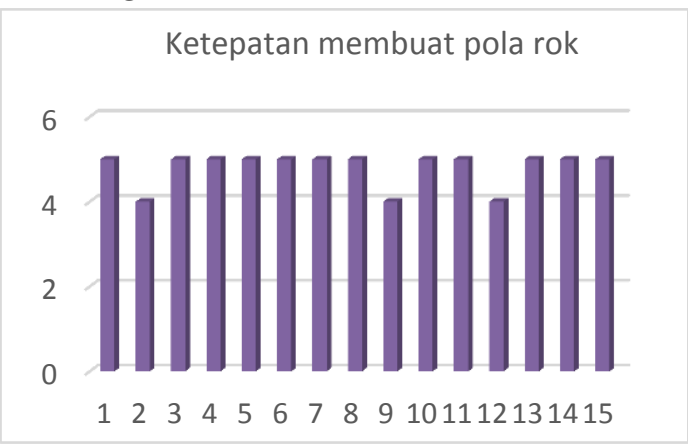

Gambar 7. Hasil postest ketepatan membuat pola rok

3. Ketepatan membuat pola blus

Indikator selanjutnya adalah ketepatan dalam membuat pola blus. Setelah melaksanakan pretest nilai rerata yang di peroleh pada indikator ketepatan dalam membuat blus adalah 1,87 yang berada pada kategori kurang kompeten. Dapat dilihat pada diagram dibawah ini:

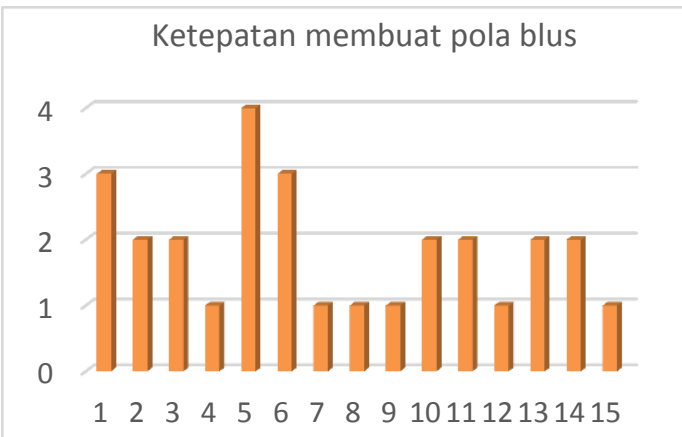

Gambar 8. Hasil pretest ketepatan dalam membuat pola blus

Hasil postest setelah pelaksanaan pelatihan pada indikator ketepatan membuat pola rok memperoleh rerata 4,47 dan berada pada kategori kompeten. Dapat dilihat pada diagram dibawah ini:

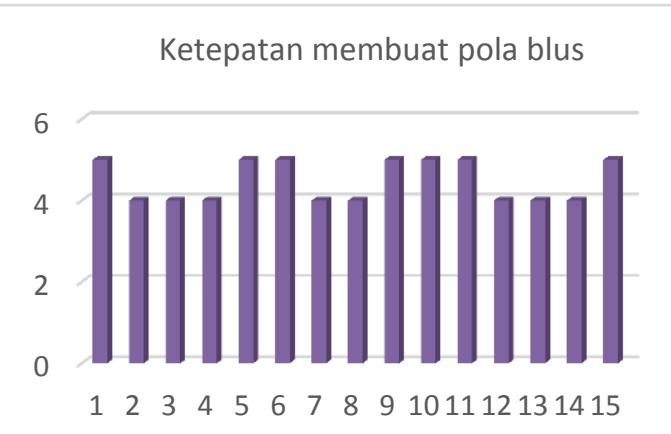

Gambar 9. Hasil postest ketepatan dalam membuat pola blus 


\section{Journal of Millennial Community, 2 (1), March 2020 - 1 \\ Nurhijrah, Nasrah Natsir}

4. Ketepatan waktu dalam membuat pola

Dalam membuat pola ketepatan waktu penyelesaian pola merupakan salah sati indikator yang sangat memberikan pengaruh. Hasil pretest menunjukkan berda pada rerata 1,20 yang berada pada kategori tidak kompeten. Dapat dilihat pada diagram berikut:

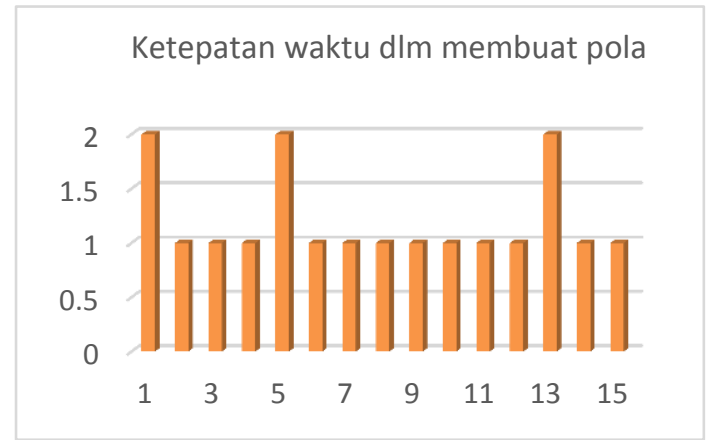

Gambar 10. Hasil pretest ketepatan waktu dalam membuat pola

Hasil postest setelah guru-guru mendapatkan pelatihan membuat pola digital menggunakan CAD System menunjukkan bahwa ketepatan waktu dalam membuat pola memperoleh rerata 4,67 yang berada pada kategori sangat kompeten. Dapat dilihat pada diagram berikut:

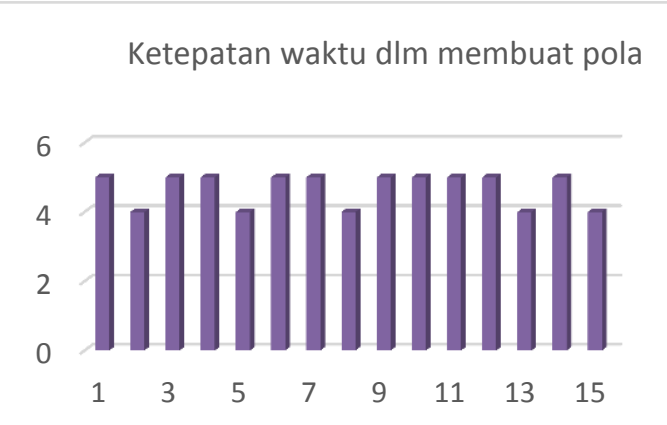

Gambar 11. Hasil postest ketepatan waktu dalam membuat pola

\section{e. Evaluation}

Tahap selanjutnya adalah tahap evaluasi, pada tahap ini adalah mempelajari apakah pengembangan komptensi guru SMK Tata Busana telah mencapai tujuan yang telah ditentukan sebelumnya yaitu meningkatkan kompetensi guru dalam membuat pola digital dengan menggunakan $C A D$ System. Tahap evaluasi ini terdiri dari hasil pretest dan postest guru-guru SMK Tata Busana di Kota Makassar yaitu berupa hasil belajar peserta baik sebelum maupu setelah mengikuti pelatihan baiksecara manua maupun dengan menggunakan $C A D$ System.

\section{SIMPULAN}

Pengembangan kompetensi guru dalam membuat pola digital dengan Page 43 menggunakan $C A D$ System adalah penelitian pengembangan $(R \& D)$, yang mengacu pada model pengembangan ADDIE yaitu: analysis, Design, Development, Implementation, Evaluation. Hasil penelitian menunjukkan adanya peningkatan kompetensi guru SMK Tata Busana dalam membuat pola digital menggunakan $C A D$ System dengan melihat peningkatan dalam setiap indikator penilaian yang rata-rata berada pada kriteria sangat kompeten setelah melakukan pretest dan postest.

\section{DAFTAR PUSTAKA}

Cahyana, Ade. (2010). Pengembangan Kompetensi Profesional Guru dalam Menghadapi Sertifikasi. Jurnal Pendidikan dan Kebudayaan, 16(1), 8591.

Kartowagiran, Badrun. (2011). Kinerja Guru Profesional (Guru Pasca Sertifikasi). Jurnal Cakrawala Pendidikan, XXX (3), 463-473.

Musfah, Jejen. (2012). Peningkatan Kompetensi Guru. Jakarta: Kencana Prenada Media Group.

Laidiah dkk, Arfah. (2017). Menguasai software CAD Pattern Making. Jakarta: Direktorat Pembinaan Sekolah Menengah dan Kejuruan.

Salirawati, Das. (2008). Spesialisasi Materi Ajar sebagai Upaya Pengembangan Profesionalisme Guru, Jurnal Cakrawala Pendidikan, XXVII (3), 232240.

Suparman, Atwi. (2012). Desain instruksional Moderen. Jakarta: Penerbit Erlangga.

Undang-Undang Republik Indonesia Nomor 14 tahun 2005 Tentang Guru dan dosen. (2014). Jakarta: Sinar Grafika.

\section{PROFIL SINGKAT}

Penulis pertama Nurhijrah, lahir di Sungguminasa pada tanggal 16 September 
Journal of Millennial Community, 2 (1), March 2020 - 1

Nurhijrah, Nasrah Natsir

1985. Pendidkan S1 di Universitas Negeri Makassar Jurusan Pendidikan Kesejahteraan Keluarga Konsentrasi Pendidikan Tata Busana dan lulus pada tahun 2008. Pada tahun 2014 melanjutkan pendidikan S2 di Universitas Negeri Makassar Jurusan Pendidikan Teknologi dan Kejuruan Konsentrasi Pendidikan Tata Busana dan lulus pada tahun 2016. Pekerjaan sebagai dosen di Jurusan Pendidikan Kesejahteraan Keluarga, Fakultas Teknik Universitas Negeri Makassar.
Penulis kedua Nasrah Natsir, lahir di Polman pada tanggal 3 Februari 1986. Pendidikan S1 di Universitas Negeri Makassar Jurusan Pendidikan Luar Sekolah dan lulus pada tahun 2009. Pada tahun 2010 melanjutkan pendidikan S2 di Universitas Negeri Yogyakarta Jurusan Pendidikan Luar Sekolah dan lulus pada tahun 2012. Pekerjaan sebagai dosen di Jurusan Pendidikan Luar Sekolah Fakultas Ilmu Pendidikan Universitas Negeri Makassar. 